region is caused by nucleic acid impurities or whether it constitutes an essential part of the antigen spec. trum. A stock solution containing $3 \mathrm{mgm}$. $/ \mathrm{ml}$. of the fraction fixes complement in dilutions as high as $1: 6,400$ with sera of cattle naturally infected or immunized with Johne's bacilli. As an antigen for routine diagnostic tests it shows less tendency to produce non-specific reactions, but is still strongly reactive with antisere containing antibodies from avian tubercle bacilli²

The co-operation of Dr. C. E. Rice in testing the fractions and discussing the results and of Dr. $H$. Konst in supplying the cultures is gratefully acknowledged. Thanks are due to Mr. F. G. Larose for his valuable technical assistance.

Animal Diseases Research Institute,

E. Annat

Department of Agriculture, 100 Gamelin Blvd.,

Hull, Quebec.

Jan. 30.

' Schuster, H., Schram, M. G., and Zillig, W., Z. Naturfsch., 11/6, 339 (1956).

${ }^{2}$ Rice, C. E., Konst, H., Connell, R., and Annau, E., Canad. J. Comp. Med. (in the press).

\section{Calcium Exchanges of Ehrlich Ascites Tumour Cells of Mice}

SINCE changes in cell calcium content and metabolism have been invoked hypothetically as contribu. tory factors, both in the irradiation syndrome ${ }^{1}$ and in the appearance of malignancy ${ }^{2}$, it seemed of interest to make a detailed study of calcium exchanges in the favourable material provided by the Ehrlich ascites tumours of mice.

In preliminary experiments with 8 mice bearing 9-day tumours, the mean calcium content was found to be $12 \cdot 0 \pm 1 \cdot 3 \mu \mathrm{gm}$. (standard error) per $100 \mathrm{mgm}$. wet weight of packed tumour cells. This value is close to that obtained by Lansing et al. ${ }^{3}$ for mouse epidermal carcinoma (9 $\mathrm{ggm}$. per $100 \mathrm{mgm}$.).

When doses of about $20 \mu \mathrm{c}$. of a sample of calcium. 45 of high specific activity were injected into the peritoneal cavity, the tumour cells rapidly became 'labelled'. Within a few minutes the radioactivity per unit wet weight of cells and fluid were approximately equal. Since no significant difference was found between calcium concentration in cells and fluid, the specific activities also must have been similar. This result indicates complete exchangeability of the cell calcium, and contrasts sharply with the results obtained by Harris ${ }^{4}$, who studied museles in vitro.

Further work in progress includes the comparative study of calcium exchanges of freely suspended non-tumour cells, and of irradiated normal and malignant cells. Details of this investigation will be published elsewhere.

\section{DOREen Thomason} RAYMOND SCHOFIELD

Christie Hospital and Holt Radium Institute, Withington Manchester, 20. Feb. 10. "Beilbrunn, L. V., and Mazia, D., "Biological Effects of Radiations".

'Coman, D. R., Cancer Res., 13, 397 (1953).,

'Lansing, A. I., et al., Arch. Biochem., 19, 177 (1948)

- Harrí, E. J., Biochim. Biophys. Acta, 23, 80 (1957).

\section{Thermal Decomposition of Some Antibiotics}

As part of our programme on the thermal decomposition of antibiotics ${ }^{1}$, additional studies have been made to include the antibiotics, aureomycin (chlortetracycline), terramycin and tetracycline.

The thermal decomposition of the antibiotics was studied by means of an automatic recording thermobalance ${ }^{2}$. Sample sizes ranged from 40 to $60 \mathrm{mgm}$. and were subjected to a linear heating-rate of $5.4 \mathrm{deg}$. C. per min. During the pyrolysis, a slow stream of air was passed over the sample to remove the decom. position products from the furnace.

The resulting thermograms of aureomycin, aureomycin hydrochloride, terramycin and tetracycline hydrochloride are given in Fig. 1. In general, the antibiotics studied were surprisingly stable. The thermobalance, of course, can only detect decom. position if a resulting loss in weight occurs. Using this as a criteria for establishing decomposition, the antibiotics were stable up to the $145-170^{\circ} \mathrm{C}$. temperature-range.

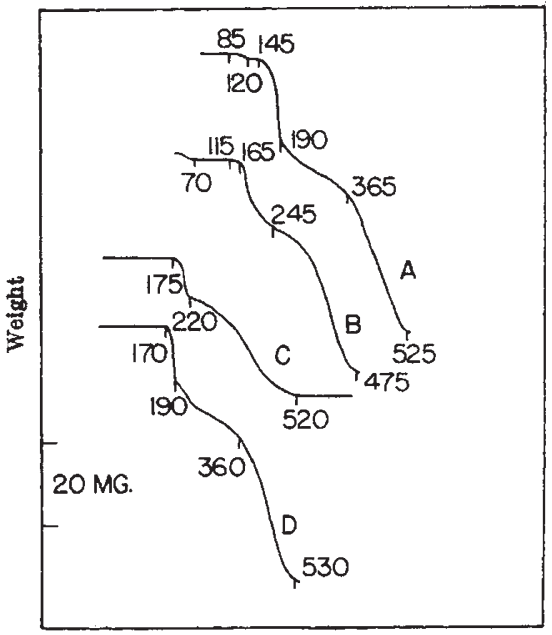

Temperature $\left({ }^{\circ} \mathrm{C}\right.$.

Fig. 1. Thermograms of antibiotics. $A$, Tetracycline hydrochloride; $B$, terramyein; $C$, aureomycin; $D$, aureomycin

Tetracycline hydrochloride (Fig. 1, curve $A$ ) began gradually to lose weight beginning at $85^{\circ} \mathrm{C}$. From $120^{\circ}$ to $145^{\circ} \mathrm{C}$. a horizontal weight-level was observed which probably corresponded to the anhydrous antibiotic. This first loss in weight is thought to be due to loosely bound water. Beyond $145^{\circ} \mathrm{C}$, total disruption and oxidation of the organic material occurred, resulting in an empty thermobalance pan at $525^{\circ} \mathrm{C}$

Terramycin (curve $B$ ) lost a small amount of water at a little above room temperature, giving a horizontal weight-level from $70^{\circ}$ to $115^{\circ} \mathrm{C}$. which corresponded to the anhydrous antibiotic. Rapid disruption and oxidation took place above $165^{\circ} \mathrm{C}$., resulting in an empty thermobalance pan at $475^{\circ} \mathrm{C}$.

Aureomycin (curve $C$ ) was thermally stable up to $175^{\circ} \mathrm{C}$. According to Broschard et al..$^{\mathrm{s}}$, the melting point of the antibiotic is $168-69^{\circ} \mathrm{C}$. (uncorr.), just a little below the temperature where rapid weight loss began. Above $175^{\circ} \mathrm{C}$. the antibiotis decomposed 